コンファレンスレポート

\title{
CLEO'89/QELS'89報告 IV
}

—レーザープロセス, ガスレーザー, 自由電子レーザー—

前田三男 ${ }^{*}$. 大道博行

Report on CLEO' 89/QELS' 89 IV

- Laser Processing, Gas Lasers, Free Electron Lasers -

Mitsuo MAEDA* and Hiroyuki DAIDO**

\section{1. はじめに}

CLEO におけるレーザープロセス関連の発 表は,レーザー側からみた新しい手法の試みや 基礎過程の研究に重点がおかれていて, その数 はかならずしも多くない。今回はエキシマレ ーザーによるプラスチックのアブレーションに 関して比較的まとまった発表があった。プロセ ス計測については, 会議の性格上レーザー分光 法の応用が圧倒的に多い。

気体レーザーに関しては，エキシマレーザ 一についての研究報告が非常に多いが，一般的 には他の項で紹介されるものと思われるので, 本項ではプロセスの側から見た放電型エキシマ レーザーについて述べる。また, 高出力 $\mathrm{Cu}$ 蒸気レーザー, ケミカルレーザーなどについて も若干紹介した。

\section{2.レーザープロセス}

紫外レーザーによるポリマーのアブレーショ
ンは，すでにマイクロエレクトロニクスや医学 などで活用されているが, そのメカニズムはか ならずしも明確にされていない。フランスの Lazare らはエッチングの動力学モデルを作り, その過程がアブレーション率 $k$ とスクリーニン グ係数 $\beta$ のつで記述できることを示した。各 種のポリマーについて $k$ と $\beta$ の值を測定し, フ ルエンスとエッチング速度の関係を求め, 実験 と良い一致を見ている（ThD1）。マックスプラ ンク研究所け Kuper らは, PMMA の 248 nm 光によるエッチング機構を赤外フーリエ分光と 紫外吸収分光とで究明し，アブレーション開始 後エッチング速度が速くなってゆく原因を, 光 を良く吸収するエステルの生成によるとしてい

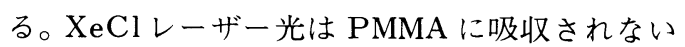
が，あらかじめUVランプ (257 nm)をあてて おくと，その部分に吸収物質ができて，選択的 エッチングができる（ThD2）。

IBMのSrinivasan らはポリマーがよく吸収 する波長としない波長（たとえば PMMA では

九九州大学工学部電気工学科（干812 福岡市東区箱崎 6-10-1)

**大阪大学レーザー核融合研究センター ( 5565 吹田市山田丘 $2-6$ )

* Department of Electrical Engineering, Faculty of Engineering, Kyushu University, (6-10-1, Hakozaki,

Higashi-ku, Fukuoka, 812).

* * Institute of Laser Engineering, Osaka University (2-6, Yamadaoka, Suita, Osaka 565). 
$193 \mathrm{~nm}$ と $308 \mathrm{~nm}$, PET では $308 \mathrm{~nm}$ と 351 $\mathrm{nm}$ ）を混合して照射すると，エッチング速度 が改善することを示した。これはアブレーショ ンが分子内の発色団（chromophore）の励起準 位を経由して起こることで説明できる（ThD 4)。

金属のアブレーションはプラズマが生成され るような高いパワー密度領域で起こる。IBMの Dreyfus は招待講演において，ラングミュア プローブとレーザー誘起蛍光法 (LIF) を用い てCuのアブレーションプラズマの計測につい て報告した。LIFではスペクトルのドプラーシ フトから $\mathrm{Cu} \mathrm{Cu}^{+}$の速度を求めている( $\left.\mathrm{ThD} 3\right)$ 。 オーストラリアの Keenらのグループは $10^{8} \mathrm{~W}$ $/ \mathrm{cm}^{2}$ の KrFレーザー光を金属 $(\mathrm{Pt}, \mathrm{Cu}, \mathrm{Ni})$ 表 面に照射して, 粒径 $5 \sim 20 \mathrm{~nm}$ の超微粒子の生 成を行なっている。

Postdeadline paper において東海大の村原 は, X線用の $\mathrm{SiC}$ 回折格子の作製をレーザーエ ッチング法により行なったことを報告した。こ れは $\mathrm{KrF} レ$ ザーを二方向から入射して干渉 縞を作るとともに, $\mathrm{XeF} レ$ ーザー光を面に平 行に入射して $\mathrm{ClF}_{3}$ ガスの解離を行なったもの である (PD24)。この他，エッチング技術はポ リマー導波路の結合溝の加工 (WF54), GaAs 光IC の導波路作製 (FF4), 超電導物質 $\mathrm{YBa}_{2}$ $\mathrm{Cu}_{3} \mathrm{O}_{7-x}$ フィルムの加工 $(\mathrm{FF} 6)$ などにも使わ れている。

レーザーCVDの応用に関して, NEC から 2 件（FF1，2）の報告があった。1 件は金属(W， Mo など）のデポジションによってLSI リード 線の修正を行う装置で, パルス幅 $100 \mathrm{~ns}, 10$ $\mathrm{kHz}$ の Q スッチ YAGレーザーの SHG が使 われている。もう 1 件は液晶デイスプレイを構 成する TFT(Thin Film Transistor)の直接描

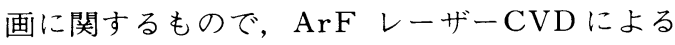
$\alpha-\mathrm{Si}: \mathrm{H}$ フィル生成技術が使われている。

ルイジアナ州立大学の Norton らは, ArF レーザーあるいは $\mathrm{Hg}-\mathrm{Xe}$ ランプによるGaAs 単結晶膜の低温におけるデポジションについて 報告している $(\mathrm{FF} 3)$ 。イリノイ大学のColeman
は, GaAs 基板上の $\mathrm{Ge} の$ laser-assisted MOCVDにおいて, アンモニヤを増感材として 用いれば，成長速度が約 200 倍増加することを 見出した（FN3）。

ラザフォード研究所の Davis らは, 強誘電 性を持つ $\mathrm{BaTiO}_{3}$ 粉末の $\mathrm{XeCl}$ レーザーによ るアブレーションを利用したエピタキシャル生 成について報告している。 $\mathrm{LiF}$ 基板上に 0.3 $\mu \mathrm{m}$ の $\mathrm{BaTiO}_{3}$ 結晶膜が生成した（WF59）。

\section{3. プロセス及び燃焼計測}

九州大学の岡田らは, 炭素系ガスの光 C V D 生成物 $\mathrm{CH}, \mathrm{C}_{2}, \mathrm{CH}_{3}, \mathrm{H}$ などのレーザー誘起蛍 光 (LIF) および共鳴イオン化法（RIS）によ る計測について発表した。色素レーザープロー ブにより，生成したラジカル密度の時間・空間 分布が計測できるので，それから反応定数や拡 散係数を決定できる（FNl）。

コロンビヤ大学の Tang らは, $\mathrm{Si} の \mathrm{Cl}_{2}$ ガ スによる光エッチング時の表面計測にラマンマ イクロプローブを用いた。Ar レーザー光を直 径 $0.6 \mu \mathrm{m}$ に集光し, サブミクロンの分解能を 得た。また LIF による $\mathrm{HSiCl}$ の計測も行った (FN2)。オリン研究センターのHansen らはフ ルオロカーボンのプラズマプロセスで発生する $\mathrm{CF}$ 及び $\mathrm{CF}_{2}$ の密度分布をエキシマ（193， $248 \mathrm{~nm}$ ) 光を用いた LIFで計測し, その生成 ・消滅過程を論じている（TuJ56）。

各種ポリマーの光アブレーションの際に発生 するフラグメントがtime-of-flight 質量分析 法で計測された（TuJ 55）。また, IC 表面を Ar レーザーの SHG (254 nm) でスキャンし, 放出された光電流からドープ量や金属, 酸化物 の区別などを検知する方法が提案された。これ をレーザー掃引顕微鏡に応用すれば，半導体素 子表面のマッピングが可能である（FN5）。

燃焼と流れ場の計測のセッションでは, C A R S と LIF が多用されている。スェーデンの Alden は招待講演において，回転及び振動 CARSをいっしょにした二重広帯域CARSに よる温度計測とフレーム中での $\mathrm{NO}, \mathrm{OH}, \mathrm{O}, \mathrm{C}_{2}$ 
などの LIF 計測について紹介した (ThE1)。内 燃機関中の広帯域 CARS による温度計測につ いては，サンディヤ国立研究所からも発表があ つた（ThE2）。彼等はC A R S 信号の検知を CCD メラで行なっているか，これはインテ ンシファイヤー付のダイオードアレイより優れ ており，2 次元表示が可能である (TuJ48)。 また LiFによるエンジン内の $\mathrm{OH}$ 及びアセト アルデヒドの二次元計測が報告された。 $\mathrm{XeCl}$ レーザーで励起し， CCD カメラでその分布が 求められている（TuJ47）。

サンディア研究所の Goldsmith らは 2 光子励 起でフレーム中の原子計測を行なったが, 今回 波長 $226 \mathrm{~nm}$ で $\mathrm{O}$ 原子を 2 光子励起した際, 845 $\mathrm{nm}$ で誘導放出を起こすことを見出した $(\mathrm{ThE} 3)$ 。

\section{4. 放電型エキシマーレーザー}

プロセスの側から見たエキシマレーザーに 対する関心は平均出力, 効率, くり返し周波数 の向上, スペクトル狭帯域化, 長パルス化など の点にある。

平均出力に関してはラムダ社から U V 予備電

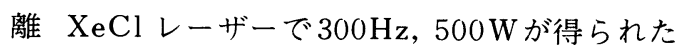
という報告があった。流速は $50 \mathrm{~m} / \mathrm{s} ， 4$ 個の专 イラトロンによる並列駆動とのことである。

EUREKA 計画ではX $\mathrm{X}$ 線予備電離により $500 \mathrm{~Hz}$

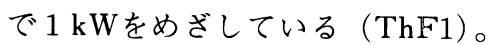

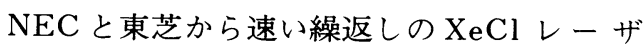
一の報告があった。 NEC は $37 \mathrm{~m} / \mathrm{s}$ という比較 的小さな流速で $2 \mathrm{kHz}$ の繰返しを得た。最大出

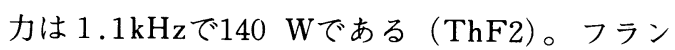
ス社は二次電子放出型の電子銃を持った X線予 備電離の $\mathrm{XeCl}$ レーザーで出力 $1.2 \mathrm{~J}$, 速い繰 返し動作では $1 \mathrm{kHz}$ で150 Wの出力を得た（W $\mathrm{F} 12)$ 。防衛庁の杉井らは $\mathrm{SrTiO}_{3}$ を絶縁体と するコロナ予備で効率 $2.3 \%$, 出力 $420 \mathrm{~mJ}$ を 得た（WF 13）。ゼネラルダイナミックス社は 電極間にグリッドを設け，それによりプリパル ス・スパイカー放電を行なわせることで, 効率 $3.5 \%$, 出力 $0.7 \mathrm{~J}$ を達成している $(\mathrm{WF} 26)$ 。 エキシマーレーザーを長パルス化すると, 波
長同調を行なったり，光ファイバーを通したり する場合に有利である。最も長パルスの動作は カナダNRCの Taylor らによって達成されて おり, $1 \mu \mathrm{s}$ で $100 \mathrm{~mJ}, 500 \mathrm{~ns}$ で0.5J の出力 が得られている。これにはセラミックコンデン サーの PLF と磁気スパイカー回路が用いられ ている。(ThF4)。ルモニクス社はスパイカー 方式でパルス幅 $200 \mathrm{~ns}$, 出力 $1 \mathrm{~J}$ を得ている。 効率は $2.2 \%$ とのことであった $(\mathrm{ThF} 5)$ 。以 上は $\mathrm{XeCl}$ の場合で, 長パルスが得られにくい $\mathrm{KrF}$ に関しても，スペクトラテクノロジー社か からはX線予備電離のスパイカー方式で最大 170 $\mathrm{ns}$ の発振が報告された（ThP6）。

スペクトルの狭帯域化は, リソグラフィー用 の光源をめざしたものである。今回は三菱電機 (ThU4), 東芝 (ThU5), ルモニクス社 (ThU 6）から発表があったが, いずれも KrFレーザ 一にエタロンを用い,フィードバック制御によ る長時間の安定化がほどこされている。三社の スペックをまとめると Table I の通りで， ほ とんど差はない。

Table I Narrowband KrF laser for lithography.

\begin{tabular}{lrrr}
\hline & Mitsubishi & Toshiba & Lumonics \\
\hline Bandwidth & $3 \mathrm{pm}$ & $3 \mathrm{pm}$ & $2.5 \mathrm{pm}$ \\
Sttability $(>1 \mathrm{~h})$ & $\pm 0.5 \mathrm{pm}$ & $\pm 0.6 \mathrm{pm}$ & $\pm 0.8 \mathrm{pm}$ \\
Repetition & $200 \mathrm{~Hz}$ & $200 \mathrm{~Hz}$ & $300 \mathrm{~Hz}$ \\
Average power & $3.6 \mathrm{~W}$ & $4.0 \mathrm{~W}$ & 6 \\
\hline
\end{tabular}

\section{5. 可視気体レーザー}

$\mathrm{Cu}$ 蒸気レーザーに関しては，オックスフォ ード社が口径 $60 \mathrm{~mm}$ で出力 $100 \mathrm{~W}$ のシステムを 発表した（W F 28）。オックスフォード大学は $511 \mathrm{~nm}$ と $578 \mathrm{~nm}$ 光を発生する二つの上位準位 位間の分布を直接計測し, $\mathrm{Cu}$ と緩衝がスとの 衝突が主なミキシング機構であることを報告し ている。しかし, 出力を一方のラインにのみ効 率良く集中させることは困難である（ThA3）。 動燃からは $\mathrm{CuBr}-\mathrm{AgBr}$ レーザーにおける $\mathrm{Cu}$ 
の高出力発振 $(14 \mathrm{~W})$ が報告された。繰返しは $40 \mathrm{kHz}$ まで可能であった（WF18）。また, $320 \mathrm{~nm}$ の U V 光で励起される $\mathrm{Cu}$ 蒸気レーザ 一も報告された（WF19）。

ケミカルレーザーに関しては，まだ基礎的な レベルであるが, 今回可視部での発振がいくつ か報告されたのが興味深かった。ジョージヤ工 科大学からは $\mathrm{Si}-\mathrm{N}_{2} \mathrm{O}$ や $\mathrm{Ge}-\mathrm{N}_{2} \mathrm{O}$ の反応によ って生じた準安定 $\mathrm{SiO}, \mathrm{GeO}\left(\mathrm{a}^{3} \Sigma^{4}, \mathrm{~b}^{3} I I\right)$ 分子 から, タリウムやガリウム原子へのエネルギー 移行によって, パルス (5 ns) 可視光 (Tl $535 \mathrm{~nm}, \mathrm{Ga} 417 \mathrm{~nm})$ のASE を得たことが 報告された $(\mathrm{TuFF} 1)$ 。また彼等は $\mathrm{Na}_{3}$ と八 ロゲン原子 $(\mathrm{Cl}, \mathrm{Br}, 1)$ の反応によって生じ た $\mathrm{Na}_{2}{ }^{*}$ において, $527 \mathrm{~nm}, 492 \mathrm{~nm}, 460.5$ $\mathrm{nm}$ の利得を観測している（TuFF2）。

レーザー開発研は, $1 \mathrm{~kW}$ のパワーレベルで 長期的に安定に動作する酸素一よう素ケミカル レーザー $(1.3 \mu \mathrm{m})$ を開発したが (THA6),

Post-deadline paper で, このレーザーが赤 色 $(670,700 \mathrm{~nm})$ の強いブロードなスペクト ルを持った光を放出することを報告している

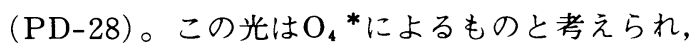
利得は $0.1 \% \mathrm{~cm}^{-1}$ であった。

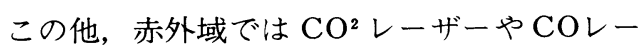
ザーに関するかなりの数の発表があったが, 著 者は聞くことができなかったので割愛する。

(前田三男)

会議最終日, CLEO, QELS 合同シンポジウ ムの自由電子レーザーのセッションが行なわれ た。最終日ということもあり講演取り消しが相 次ぎ, 聴衆も少なかった。自由電子レーザー独 自の会議が各地で頻繁に開催されており, 多く の論文がそれら会議で報告されているためであ ろう。ここでは筆者が特に印象深かった講演を 取り上げて紹介することにする。

午前のセッションでは, Brookhaven 国立研 究所の T. Srinivasan-Rao らのJK. 5 Laser driven photocathode studies for high gradient accelerators と題する講演があった。
プログラムでは一般講演になっているが招待講 演に格上げされていた。繰返し $10 \mathrm{~Hz}$, パルス幅 10 ps Nd：YAG レーザー光の 4 倍高調波光 をフォトカソードに照射し高電流密度の電子ビ 一ムを発生させようとするものである。研究の 対象として(1)フォトカソードの仕事関数の低い 材料の選定と光電子発生効率の向上, (2)フォト 'カソード印加電界の上限を決める電界破壊の解 明, 光電子放出の電界依存性の物理的解明等を 上げることができる。実験配置図を Fig. 1 に示 す。また各種フォトカソード物質の仕事関数を Table IIに示す。光電子電流はカソードに印 加した電界の低い領域では空間電荷制限領域の 電流が流れる。それを越えると field assisted photo electron emission 領域に入り電 流值は停滞する。さらに電界が上がってくると 電界放出が支配的になり電流值が上昇する。こ のような機構で電流が取り出せることもわかっ てきたようである。マグネシウムのフォトカソ ード（面積 $0.05 \mathrm{~mm}^{2}$ ）に1.1 $\mu \mathrm{J}$ のレーザー 光を照射することにより $60 \mathrm{kA} / \mathrm{cm}^{2}$ 程度の電流 值が得られており, 将来は $200 \mathrm{kA} / \mathrm{cm}^{2}$ も可能 であることが示された。改良するポイントはレ ーザー光を短パルス化（1 ps以下）することに より, フォトカソードのダメージ閥值を上げる こと等が挙げられていた。

午後のセッションでは 2 件, 招待講演があっ

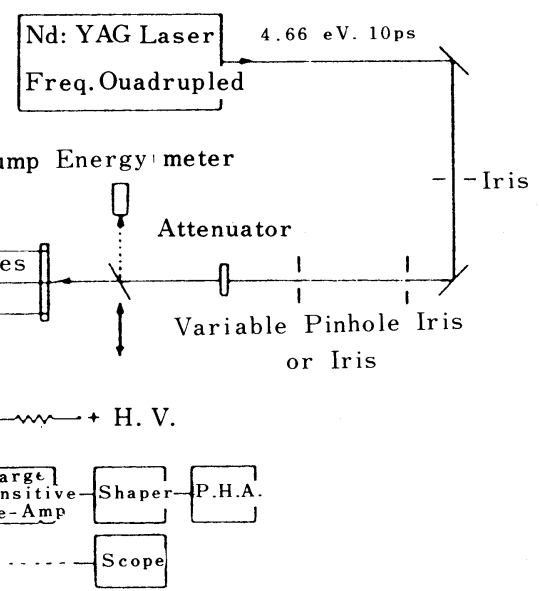

Fig. 1 Schematic of the experimental arrangement. 
Table II Work functions and observed quantum efficiencies.

\begin{tabular}{l|c|c}
\hline Material & Work function & $\begin{array}{l}\text { Measured } \\
\text { Efficiency } \\
\eta\left(\times 10^{-3}\right)\end{array}$ \\
\hline Gold & 5.1 & 0.047 \\
\hline $\mathrm{MgO}$ & 2.9 & 0.62 \\
\hline Samarium & 2.7 & 0.725 \\
\hline $\mathrm{Yt}$ & 3.1 & 0.5 \\
\hline $\mathrm{Mg}$ & 3.66 & 0.6 \\
\hline
\end{tabular}

た。最初に Lawrence Livermore National Loboratories のT. J. Orzechowski の JM1 Paladin: A. $10.6 \mu \mathrm{m}$ free-electron laser amplifier と題する講演があった。波長 10.6 $\mu \mathrm{m}, \quad ヒ ゚ ー ク ハ ゚ ワ ー 14 \mathrm{~kW} \sim 5 \mathrm{MW}$ パルス幅50 ns $\mathrm{CO}_{2}$ レーザーをマスター発振器とし周期 8 $\mathrm{cm}$, 長さ $25 \mathrm{~m}$ のウィグラー中での増幅率と増幅 光の特性測定を行なったものである。電子ビー ムのエネルギーは $45 \mathrm{MeV}$ ，電流は $500 \mathrm{~A}$ であ りインダクションライナックによりウィグラー に供給される。利得值として電子ビームエネル ギー40 MeV のとき $15-\mathrm{dB}, 42 \mathrm{MeV}$ のとき 21-dB が上げられていた。物理的興味を引い たのはいわゆる gain guiding という現象で ある。ビジコンカメラを用いた増幅光の断面強 度分布の測定を行ない, この現象の実証を行な
つている。すなわち低利得領域では増幅光のビ 一ム断面は半径方向になだらかな広がりを有し た分布になっているが利得が増すに従って断面 の中心部分にスパイク状に鋭く分布するように なっていく。これは利得により低次横モードの みが強く増幅されたことによると考えられる。 以上のとおり赤外領域では着実に高性能化, 物 理的機構の解明が進んでいるように思われた。

次に Los Alamos National Laboratories のR. W. Warren によるStatus of rf linac electron lasers と題する講演があった。種々 のタイプの自由電子レーザーが建設され初歩的 物理現象の解明が行なわれた第 1 フェーズ, 注 意深い実験的研究により重要な物理機構の解明 が行なわれた第 2 フェーズが終了し，現在は各 種ユーザーの要求に合致した自由電子レーザー システムの建設が始まろうとしている。これら 応用の可能性と現状のまとめが行なわれた。自 由電子レーザー固有の話題として加速器のプリ バンチャー，モード同期レーザーを用いたフォ トエレクトリックガン, ウェークフィールドの 効果等が取り上げられた。なお米国内，世界の 主要な RF driven 自由電子レーザー研究機関 の一覧を Table III に示す。これを見ても明ら かなようにこの分野の我国における本格的取り 組みと重要な研究成果の発表が期待されている ようである。

(大道博行)

Table III RF Driven free electron lasers.

\begin{tabular}{ll|ll}
\hline Institute & (Domestic) & Country & Institute(Foreign) \\
\hline Stanford & Mark lll & Netherland & FOM \\
& SCR & Germany & Darmstadt SC \\
LANL & France & Decas, Ortega \\
Boeing & Italy & Frascati SC \\
Plared & Japan & Many \\
Verderbilt & China & IHEP, IAE \\
Duke & Russia & \multicolumn{2}{c}{} \\
NRL & Note: SC stands for Super Conducting. \\
Bell Labs & & \\
LBL (Storage Ring) & & \\
White Sands &
\end{tabular}

